\title{
The black binder
}

James Goldenberg, MD, FAAN

Neurology ${ }^{\circledR}$ 2019;92:811-812. doi:10.1212/WNL.0000000000007377

2018. The black binder (figure) sits on the floor in the corner of my office. It is not labeled like all of the other binders on the shelf, with titles like "Bylaws," "EHR," or "Credentialing." When I moved to this office 17 years ago, I didn't know where to put it, so there it sits, on the floor, in the corner, between the bookcase and the wall.

1994. I've just finished training. Hospital rounds are busy. Between patients, I'm trying to meet as many doctors as possible to build my practice. I'm struck that some seem old and tired. I'm young and confident. I can handle anything.

I opened the binder less frequently as the years passed. These days, if I'm lucky, weeks go by and I don't even notice it is there.

The first letter came 2 years later. Then more letters. I couldn't think straight after each letter came. Not at work, or at home. Eventually, I couldn't think straight waiting for the next letter to come. At one point it seemed like the letters came every day.

The last time I opened the binder was because the credentials committee asked for an explanation. The sheets are organized neatly by tabs labeled "Correspondence," "Hospital records," and "Important papers." I browse through each section. At first, I'm sad. Then a moment later I'm glad, that after all these years I only have one black binder.

I searched the hospital records. Who was she? What was her diagnosis? What did I do? What did I do wrong?

I find what I'm looking for. In the pocket of the inside cover of the binder is a short letter, just 2 paragraphs. At the bottom of the page it says my neurologic care was perfect. The outcome wasn't perfect. Not for her-or for me.

Hospital consult for altered mental status. Negative workup. The patient was confused and agitated. All of her neurologic symptoms improved. Diagnosis: multifactorial encephalopathy, resolved.

Today, after 25 years of clinical practice, I'm moving to an administrative position. I'm packing up my office. There are books I've had since medical school and plaques that say I'm the best doctor. There are journals and a few special gifts I've saved that mark different points along the journey of a wonderful clinical career. The black binder is the last thing I touch, still on the floor in the corner.

Her shoulder was broken. It wasn't diagnosed in a timely manner. The attorney said, "Don't worry-we have an expert. You're a neurologist. You'll be fine."

You'd be surprised how often a doctor gets asked the question "Have you ever been sued?" I think you only keep track if the answer is yes.

The attorney said we have to settle. You have no choice. He tells me I didn't do anything wrong. Then why are we settling?

\section{Correspondence}

Dr. Goldenberg

Jgoldenb@ymail.com

\section{MORE ONLINE}

\section{ค Audio}

Listen to Dr. Goldenberg

read this story.

NPub.org/ghaiol 


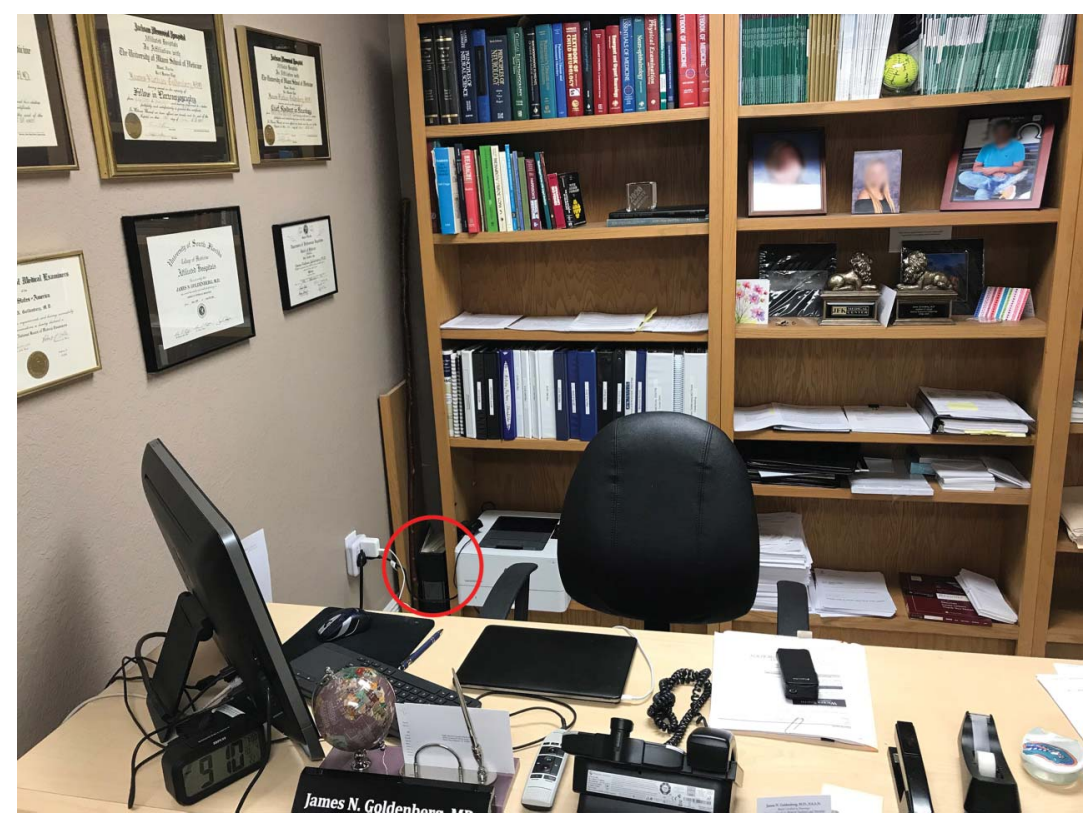

From the black binder I take out perhaps a half dozen papers, the ones I deem most important. I place them in a manila folder. I've decided the folder will come home with me and not travel to my new office. It is lighter now, literally and figuratively, more than 2 decades later. The scar is deep and permanent, but at least the black binder is gone. I wonder what her scar is like. 


\title{
Neurology
}

\author{
The black binder \\ James Goldenberg \\ Neurology 2019;92;811-812 \\ DOI 10.1212/WNL.0000000000007377
}

This information is current as of April 22, 2019

$\begin{array}{ll}\begin{array}{l}\text { Updated Information \& } \\ \text { Services }\end{array} & \begin{array}{l}\text { including high resolution figures, can be found at: } \\ \text { http://n.neurology.org/content/92/17/811.full }\end{array} \\ \text { Subspecialty Collections } & \begin{array}{l}\text { This article, along with others on similar topics, appears in the } \\ \text { following collection(s): } \\ \text { All Clinical Neurology } \\ \text { http://n.neurology.org/cgi/collection/all_clinical_neurology } \\ \text { Malpractice } \\ \text { http://n.neurology.org/cgi/collection/malpractice }\end{array} \\ & \begin{array}{l}\text { Information about reproducing this article in parts (figures,tables) or in } \\ \text { its entirety can be found online at: } \\ \text { http://www.neurology.org/about/about_the_journal\#permissions } \\ \text { Permissions \& Licensing }\end{array} \\ \text { Information about ordering reprints can be found online: } \\ \text { http://n.neurology.org/subscribers/advertise }\end{array}$

Neurology ${ }^{\circledR}$ is the official journal of the American Academy of Neurology. Published continuously since 1951, it is now a weekly with 48 issues per year. Copyright @ 2019 American Academy of Neurology. All rights reserved. Print ISSN: 0028-3878. Online ISSN: 1526-632X.

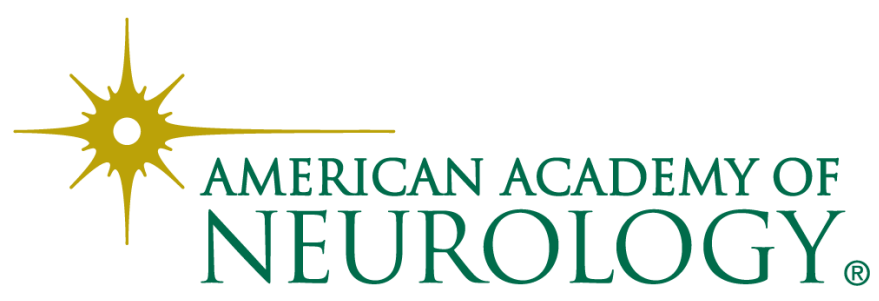

